\title{
Representasi Makna Demokrasi dalam Pidato Kampanye Presiden Jokowi
}

\author{
Representation in the Meaning of Democracy Campaign Speech \\ by the President Jokowi
}

\author{
Muh. Rajib Silmi, Esti Junining \& Nurul Chojimah \\ Universitas Brawijaya Malang, Kota Malang, Jawa Timur, Indonesia \\ mrajibsilmi@gmail.com, esti_junining@yahoo.com \& nurulchoy2@yahoo.com
}

Naskah diterima tanggal 23/10/2019, direvisi akhir tanggal 25/11/2019, disetujui tanggal 26/12/2019

\begin{abstract}
Abstrak
Bahasa adalah senjata paling tajam dan paling kuat dalam mempengaruhi masyarakat. Tujuan dari penelitian ini adalah untuk mengetahui representasi Demokrasi Pancasila dalam pidato Presiden Jokowi dan juga untuk memahami kontribusi wacana dan faktor sosial makna leksikal demokrasi. Hasil penelitian menunjukkan bahwa Presiden Jokowi menggambarkan demokrasi dalam tiga tahap yakni denotasi ( 5 data) dan konotasi ( 3 data) dalam pidato kampanyenya. Ada beberapa topik yang mewakili demokrasi seperti tentang ekonomi, kesehatan, pendidikan. Data-data tersebut disampaikan secara denotatif dan konotatif. Penelitian ini membuktikan bahwa makna leksikal adalah aspek linguistik yang tepat untuk menemukan ideologi kandidat dalam wacana terutama dalam pidato kampanye politik. Peneliti berharap penelitian ini dapat menjadi pertimbangan bagi peneliti selanjutnya yang bermaksud mengambil topik penelitiannya ini. Semoga peneliti selanjutnya melanjutkan penelitian topik ini dengan fokus pada bidang yang lebih luas daripada demokrasi karena dapat memberikan lebih banyak informasi kepada masyarakat.
\end{abstract}

Kata Kunci: Makna leksikal, demokrasi pancasila, pidato kampanye.

\begin{abstract}
Language is the sharpest and most powerful weapon in influencing society. The purpose of this study is to determine the representation of Pancasila Democracy in President Jokowi's speech and also to understand the contribution of discourse and social factors to the lexical meaning of democracy. The results showed that President Jokowi described democracy in three stages, namely denotation (5 data) and connotation (3 data) in his campaign speech. Several topics represent democracy, such as economics, health, education. The data is submitted denotatively and connotatively. This research proves that the lexical meaning is the right linguistic aspect to find candidate ideology in the discourse, especially in political campaign speeches. Researchers hope this research can be a consideration for future researchers who intend to take this research topic. Hopefully, the next researcher will continue researching this topic with a focus on a broader field than democracy because it can provide more information to the public.
\end{abstract}

Keywords: Lexical meaning, democracy pancasila, campaign speech.

\section{PENDAHULUAN}

Bahasa menurut Walija (1996) merupakan komunikasi yang paling lengkap dan efektif untuk menyampaikan ide, pesan, maksud, perasaan pada suatu pendapat kepada orang lain serta senjata paling tajam dan paling kuat dalam mempengaruhi masyarakat. Pilihan kata-kata dan penggunaan bahasa yang tepat dalam mewakili konsep dengan baik dapat memiliki efek (reaksi) tertentu 
seperti mengubah atau membangun pola pikir masyarakat. Apa yang diungkapkan, katakan, dan lakukan, adalah pesan yang dilihat oleh orang lain (diterima) dan kemudian akan menimbulkan respons atau reaksi (Soyomukti, 2013).

Mempelajari wacana tentu saja menggunakan pendekatan analisis wacana kritis. Studi analisis wacana bukan sekedar mengenai pernyataan (kumpulan kalimat), melainkan juga mengkaji struktur dan tata aturan dari wacana seperti latar, situasi, dan kondisi dalam mengekpresikan realitas (Saharuna, 2016; Wijana \& Rohmadi, 2009). Pada analisis wacana kritis, diperlukan pula studi linguistik kuat agar dapat diketahui ideologi suatu individu atau kelompok karena ada banyak cara bagi tiap individu atau kelompok dalam menyampaikan ideologinya antara lain melalui iklan, dialog sehari-hari, pidato, bahkan kampanye politik. Pidato merupakan salah satu kegiatan penting yang dilakukan oleh pemimpin dalam komunikasi pada suatu organisasi/komunitas, salah satu komunitas tersebut ialah calon pemimpin negara dengan melakukan kampanye (Mukoyimah, 2018).

Dalam kampanye politik, sulit disangkal bahwa bahasa sangat berarti dalam kampanye politik. Sebagai salah satu bukti, Presiden Joko Widodo (Jokowi) memenangkan pemilihan gubernur Jakarta dan juga pemilihan presiden Indonesia menggunakan gaya bahasanya sendiri. Tindak tutur makna leksikalnya, pilihan leksikal, dan lain-lain yang dinyatakan dalam visi, misinya, dan juga kampanye politiknya, telah menarik orang Indonesia untuk memilihnya sebagai Presiden Indonesia pada tahun 2014 dan juga menjadi kandidat untuk pemilihan presiden berikutnya.

Pemilihan presiden dan wakil presiden Indonesia berikutnya akan diadakan pada tahun 2019. Komisi Pemilihan Umum, di Indonesia kami menyebutnya sebagai Komisi Pemilihan Umum (KPU) sebagai administrator menyatakan bahwa para kandidat telah diumumkan pada awal Agustus 2018. Ada hanya dua orang yang mengikuti kompetisi kandidat presiden, mereka adalah Prabowo Subianto dan Joko Widodo. Sebagai petahana, ada banyak kritik yang disampaikan kepada Presiden Jokowi. CNN Indonesia (2018) menyatakan bahwa ketika datang ke tahun politik, ada banyak kritik yang dikirim ke Presiden Jokowi seperti komunisme dan pelayan orang asing. Kata komunisme muncul oleh anti-Jokowi, itu karena mereka berpikir bahwa Jokowi tidak serius mengurus masalah tentang komunisme. Sementara kata pelayan asing juga muncul oleh anti-Jokowi karena mereka menganggap Presiden Jokowi memberikan banyak peluang kepada orang asing untuk berinvestasi di Indonesia.

Dalam menganalisis bahasa Presiden Jokowi, kita dapat menggunakan Analisis Wacana. Namun, itu hanya untuk mengetahui fitur bahasa yang digunakan oleh Presiden Jokowi, bukan alasan di balik bahasa Presiden Jokowi. Sementara untuk mengetahui bahasa dan ideologi Jokowi, alasan di balik bahasa Jokowi, kita dapat menggunakan Analisis Wacana Kritis (AWK). Sedangkan Fairclough (1995) menyatakan bahwa AWK melihat hubungan antara bahasa dan struktur sosial secara umum. AWK membahas masalah sosial yang lebih luas dan memperhatikan faktor-faktor eksternal, termasuk ideologi, kekuasaan, ketidaksetaraan, mengacu pada teori sosial dan filosofis untuk menganalisis dan menafsirkan teks tertulis atau lisan.

AWK adalah studi bagaimana bahasa tata bahasa membawa ideologi tertentu di dalamnya. Aspek ideologis dapat ditemukan berdasarkan makna leksikal dan struktur bahasa yang dapat digunakan oleh orang tersebut. Makna leksikal terkait erat dengan ide seseorang (Keraf, 2010). Penting untuk melakukan penelitian tentang makna leksikal karena itu mewakili ide, cara berpikir seseorang, dan tujuan pembicara. Oleh karena itu, dalam penelitian ini, peneliti tertarik untuk menemukan makna leksikal dan ideologi yang biasanya digunakan oleh Jokowi dalam mengekspresikan Demokrasi Pancasila. Peneliti ingin mengetahui alasan di balik pidatonya, yakni ideologi Jokowi berdasarkan pidatonya di beberapa tempat apakah itu mewakili orang Indonesia atau 
hanya untuk membujuk orang Indonesia untuk memilihnya lagi sebagai presiden Indonesia berikutnya.

Untuk menemukan makna leksikal dan ideology dalam pidato Jokowi, peneliti menggunakan teori makna leksikal dari Keraf (2010) dan teori analasis wacana kritis dari Fairclough (1995). Berdasarkan makna leksikal, peneliti hanya fokus pada makna konotasi dan makna denotasi yang ada pada teori Keraf (2010).

Makna konotatif menurut Suwandi (2008) sebuah atau sekelompok kata yang didasarkan atas perasaan atau pikiran yang timbul atau ditimbulkan oleh pembicaraan (penulis) dan pendengar (pembaca). Makna konotasi yang terkait atau sekunder; itu bisa berupa sesuatu yang disarankan atau tersirat oleh suatu kata atau hal daripada secara eksplisit disebutkan atau dideskripsikan. Konotasi relatif tidak stabil; yaitu, mereka sangat bervariasi sesuai dengan budaya, periode sejarah, dan pengalaman individu. Konotasi adalah kata atau kalimat yang mengandung makna tidak langsung di dalamnya seperti kata 'istirahat' dalam kalimat "Ella sekarang berbaring diam di kuburan." Kata 'istirahat' berarti berbaring mati dan dikuburkan.

Sedangkan denotasi adalah makna kebalikan dari konotasi. Menurut Djajasudarma (1999) mennyatakan makna denotatif ialah makna yang menunjukkan adanya hubungan antara konsep dengan dnia kenyataan. Denotasi adalah kata yang memiliki arti eksplisit atau langsung seperti kata 'istirahat' dalam kalimat 'Joni datang di sepanjang pantai dan memutuskan untuk berhenti dan beristirahat." Kata 'istirahat' berarti tidak melakukan apa-apa setelah periode aktivitas atau periode santai. Selanjutnya, peneliti juga menggunakan kamus bahasa Indonesia (KBBI) sebagai alat pendukung dalam menganalisis kata.

Sementara itu, Fairclough (1995) menyatakan bahwa AWK melihat hubungan antara bahasa dan struktur sosial secara umum. AWK membahas masalah sosial yang lebih luas dan memperhatikan faktor-faktor eksternal, termasuk ideologi, kekuasaan, ketimpangan, mengacu pada teori sosial dan filosofis untuk menganalisis dan menafsirkan teks tertulis atau lisan. Poin utama dari AWK oleh Fairclough adalah bagaimana kita melihat pengguna bahasa membawa ideologi mereka. Ada tiga dimensi AWK oleh Fairclough, analisis tekstual, praktik wacana, praktik sosial-budaya.

Pertama, dalam menganalisis teks, ini adalah tentang deskripsi teks. Ia melihat bagaimana penggunaan fitur bahasa (pilihan leksikal, makna leksikal, tata bahasa, tindak tutur, dan sebagainya) dalam sebuah teks. Analisis teks mencakup analisis tentang bagaimana genre, wacana, dan gaya diartikulasikan bersama. Pada dasarnya, ini adalah proses penafsiran teks.

Kedua, praktik wacana, ini tentang bagaimana teks diproduksi dan dikonsumsi. Dalam praktik wacana, Fairclough menekankan pentingnya menyelidiki proses produksi teks dan kondisi sosial yang muncul dari teks. Selain itu, proses penafsiran juga muncul di dimensi kedua, di mana proses penafsiran mengacu pada bagaimana teks dikonsumsi dan ditafsirkan oleh pembaca.

Ketiga, praktik sosial-budaya, itu adalah dimensi yang terkait dengan konteks di luar teks. Ini menggambarkan penjelasan tentang proses sosial dalam wacana. Pembahasan praktik sosial budaya mencakup tiga tingkatan, yaitu tingkat situasional, kelembagaan dan sosial. Level situasional, terkait dengan produksi dan konteks situasi. Tingkat kelembagaan, terkait dengan pengaruh lembaga secara internal dan eksternal. Tingkat sosial terkait dengan situasi yang lebih besar, seperti sistem politik, sistem ekonomi, dan sistem budaya masyarakat secara keseluruhan.

\section{METODE PENELITIAN}

Desain penelitian kualitatif yang digunakan dalam penelitian ini adalah analisis wacana kritis. Desain ini terkait dengan Fairclough yang memandang wacana sebagai bentuk dan praktik sosial. Peneliti memilih AWK oleh Fairclough sebagai desain penelitian karena penelitian ini tidak berhenti pada tingkat penjelasan bahasa, 
tetapi juga peneliti ingin menghubungkannya dengan konteks sosial untuk tujuan dan praktik tertentu (Fairclough, 1995).

Pada bagian ini, ada dua contoh pidato sebagai data penelitian yang digunakan oleh peneliti. Namun, peneliti hanya mengambil video yang berisi seluruh pidato Jokowi sehingga lebih mudah bagi peneliti untuk menemukan data penelitian. Pertama, data penelitian adalah makna leksikal yang menunjukkan cara berpikir Jokowi berdasarkan pidatonya yang disampaikan pada konsesi sipil di Sentul International Convention Center, Bogor, Jawa Barat. Kedua, pidato yang disampaikan setelah Presiden Jokowi resmi terdaftar sebagai calon di Aula KPU. Sedangkan sumber data diambil dari beberapa saluran youtube yang memiliki keseluruhan pidato seperti saluran youtube CNN Indonesia, saluran youtube Metro TV. Dalam penelitian ini, ada beberapa langkah yang digunakan oleh peneliti untuk mengumpulkan data seperti mengunduh video, menyalin teks, membaca teks secara menyeluruh, dan mencatat.

Peneliti mengunduh video dari beberapa saluran youtube di www.youtube. com dengan mengunduh video. Peneliti memilih beberapa video pidato Jokowi pada tahun 2019 selama masa kampanye karena peneliti ingin mengetahui ideologi Presiden Jokowi berdasarkan pidatonya ketika ia mencoba menjadi Presiden Indonesia untuk kedua kalinya. Setelah mengunduh data dari www.youtube.com, peneliti menyalin teks itu sendiri. Transkripsi didasarkan pada ucapan Jokowi dalam pidatonya. Itu membantu peneliti untuk mengamati pidato nanti. Kemudian, teknik pengumpulan data yang digunakan oleh peneliti adalah observasi yakni metode atau cara-cara menganalisis dan mengadakan pencatatan secara sistematis (Basrowi \& Suwandi, 2008). Peneliti menggunakan teknik observasi untuk mengamati bagaimana bahasa yang digunakan, terutama makna leksikal, terkait dengan kalimat yang menyarankan demokrasi. Cara untuk mengamati data adalah dengan membaca teks pidato dengan hati-hati. Setelah membaca teks dengan seksama, peneliti memberikan beberapa catatan berdasarkan teks. Pembuatan catatan di sini digunakan sebagai kombinasi dari pengamatan dengan berfokus pada makna leksikal yang digunakan oleh Jokowi dalam pidatonya.

Setelah mengumpulkan data, peneliti menganalisis data berdasarkan dimensi Fairclough. Ada tiga dimensi Fairclough seperti deskripsi teks, interpretasi praktik wacana, dan penjelasan praktiksosiokultural. Berdasarkan dimensi tersebut, oleh karena itu, peneliti menganalisis data dalam tiga langkah seperti deskripsi teks, interpretasi praktik wacana, dan penjelasan praktik sosiokultural. Pertama, dalam menganalisis teks, ini adalah tentang deskripsi teks. Analisis teks termasuk analisis tentang bagaimana genre, wacana, dan gaya diartikulasikan bersama. Pada bagian ini, peneliti hanya menganalisis teks melalui makna leksikal yang mewakili demokrasi (terutama demokrasi Pancasila) dengan menggunakan teori semantik berdasarkan teori Keraf (2010). Hasil analisis teks mengarahkan peneliti untuk melanjutkan ke langkah berikutnya. Kedua, dalam praktik diskursif, karena data adalah makna leksikal yang digunakan dalam pidato Jokowi, peneliti mengeksplorasi tentang hal-hal yang terhubung dengan Presiden Jokowi seperti latar belakang politik Presiden Jokowi, beberapa fenomena yang berkaitan dengan era Jokowi sebagai pemimpin. Temuan fase ini adalah faktor internal yang berkontribusi pada pilihan leksikal yang digunakan oleh Jokowi. Ketiga, dalam praktik sosiokultural, dimensi ini mengeksplorasi wacana apa yang menyebar di masyarakat karena masyarakat dan bahasa saling memengaruhi. Dalam langkah ini, peneliti menggali lebih banyak informasi tentang fenomena yang terjadi di masyarakat terutama yang berkaitan dengan situasi politik di era Jokowi ketika presiden kemudian menghubungkannya dengan pidato Presiden Jokowi. Ini didasarkan pada faktor-faktor eksternal yang berkontribusi pada makna leksikal yang digunakan oleh Presiden Jokowi. 


\section{HASIL DAN PEMBAHASAN}

\subsection{Hasil}

Bagian ini berisi temuan dan analisis makna leksikal dalam kampanye pidato Presiden Jokowi. Penjelasannya adalah sebagai berikut:

Representasi Demokrasi Pancasila Berdasarkan Teks Pidato Presiden Jokowi.

Pada bagian ini, peneliti fokus pada pidato yang telah ditranskripsikan. Temuan bagian ini dibagi menjadi dua bagian seperti makna leksikal dan ucapan persuasif. Penjelasannya adalah sebagai berikut:

\section{a. Makna Leksikal}

Berdasarkan temuan tersebut, Presiden Jokowi menggunakan beberapa klasifikasi kata demokrasi. Penjelasannya adalah sebagai berikut:

Datum 1:

Pada kesempatan yang baik ini, saya ingin mengajak kepada seluruh rakyat Indonesia agar bersama-sama menjadikan proses Pemilu 2019 benarbenar menjadi perayaan kegembiraan dalam kita berdemokrasi.

Dalam hal ini, Presiden Jokowi langsung menggunakan kata demokrasi sebagai "berdemokrasi". Berdasarkan KBBI V (2019) kata "berdemokrasi" (v) berarti menerapkan demokrasi. Lebih jauh, makna demokrasi yang digunakan oleh Presiden Jokowi adalah tentang kebebasan memilih bagi rakyat Indonesia dalam pemilihan umum 2019. Datum ini mewakili demokrasi karena makna leksikal dalam kalimat tersebut melibatkan makna denotatif karena secara langsung menggunakan kata demokrasi. Cara denotatif di sini berarti bahwa Presiden Jokowi secara langsung menyebutkan kata demokrasi dalam bentuk "berdemokrasi".

Datum 2:

Di mana setiap orang bisa menunjukkan berdemokrasi dengan penuh kegembiraan, penuh dengan riang gembira.

Dalam hal ini, Presiden Jokowi langsung menggunakan kata demokrasi sebagai "berdemokrasi". Berdasarkan KBBI V (2019) kata "berdemokrasi" (v) berarti menerapkan demokrasi. Lebih jauh, makna demokrasi yang digunakan oleh Presiden Jokowi adalah tentang kebebasan memilih. Itu adalah tentang kebebasan rakyat Indonesia untuk memilih dalam memberikan suara mereka kepada para kandidat. Dapat disimpulkan bahwa datum ini mewakili demokrasi karena makna leksikal dalam kalimat melibatkan makna denotatif. Cara denotatif di sini berarti bahwa Presiden Jokowi secara langsung menyebutkan kata demokrasi dalam bentuk "berdemokrasi".

Datum 3:

Demokrasi bukan perang, demokrasi bukan permusuhan, tapi ajang mengadu gagasan, ajang mengadu ide, ajang mengadu rekam jejak, ajang mengadu prestasi. Jangan sampai karena perbedaan pilihan politik kita menjadi bermusuhan.

Dalam hal ini, Presiden Jokowi langsung menggunakan kata "demokrasi" (n). Makna demokrasi yang digunakan oleh Presiden Jokowi adalah tentang proses pemilihan umum di mana orang Indonesia memiliki kebebasan untuk memilih kandidat yang mereka inginkan. Lebih lanjut, ia juga menambahkan beberapa penjelasan bahwa proses demokrasi harus dengan cara intelektualisme. Dapat disimpulkan bahwa data ini mewakili demokrasi karena makna leksikal dalam kalimat melibatkan makna denotatif. Cara denotatif di sini berarti bahwa Presiden Jokowi secara langsung menyebut kata demokrasi dalam bentuk "demokrasi". Datum 4:

Saya rasa itu yang penting yang bisa saya sampaikan. Sekali lagi marilah kita tebarkan kegembiraan dalam berdemokrasi selama Pemilu 2019.

Dalam hal ini, Presiden Jokowi langsung menggunakan kata demokrasi sebagai "berdemokrasi". Dia mengulangi kata "berdemokrasi" seperti yang dia gunakan sebelumnya. Berdasarkan KBBI V (2019) kata "berdemokrasi" (v) berarti menerapkan demokrasi. Dapat disimpulkan bahwa data ini mewakili demokrasi karena makna leksikal dalam kalimat melibatkan makna denotatif. Cara denotatif di sini berarti bahwa Presiden Jokowi secara langsung menyebutkan kata 
demokrasi dalam bentuk "berdemokrasi".

Datum 5:

Kita bangun demokrasi yang sehat. Marilah kita menatap masa depan Indonesia yang maju dengan penuh optimisme, dengan penuh percaya diri, karena kita adalah bangsa yang besar dan bersama-sama kita pasti bisa meneruskan perjalanan berupa Indonesia yang lebih baik menuju masa depan yang lebih baik.

Dalam hal ini, Presiden Jokowi langsung menggunakan kata "demokrasi" (n). Makna demokrasi yang digunakan oleh Presiden Jokowi adalah tentang proses pemilihan umum di mana orang Indonesia memiliki kebebasan untuk memilih kandidat yang mereka inginkan. Dapat disimpulkan bahwa data ini mewakili demokrasi karena makna leksikal dalam kalimat melibatkan makna denotatif. Cara denotatif di sini berarti bahwa Presiden Jokowi secara langsung menyebut kata demokrasi dalam bentuk "demokrasi".

Datum 6:

Bapak-Ibu saudara sebangsa dan setanah air, rakyat Indonesia yang saya cintai, jelas bahwa komitmen kita, komitmen kita semuanya terus menjaga dan merawat nilai luhur Pancasila. Dan tentu saja programprogram yang bertumpu dan berpihak kepada rakyat, apapun daerah dan dari mana asalnya, tanpa terkecuali, sekali lagi semua yang kita kerjakan untuk negara, untuk rakyat Indonesia.

Pidato Presiden Jokowi berdasarkan wacana itu menunjukkan bahwa Presiden Jokowi secara langsung menerapkan nilai Demokrasi Pancasila dan mencoba meyakinkan orang Indonesia dengan mengatakan bahwa semua yang telah ia lakukan adalah untuk rakyat Indonesia. Semua program didasarkan pada orang Indonesia dan untuk orang Indonesia. Itu bisa berarti bahwa Presiden Jokowi menerapkan satu pilar Demokrasi Pancasila yang disebut kesetaraan. Data-data ini mewakili demokrasi meskipun makna leksikal dalam kalimat tersebut tampaknya tidak mewakili demokrasi bahkan itu mewakili makna demokrasi atau dalam hal ini adalah dalam arti konotatif. Cara konotatif di sini berarti bahwa Presiden Jokowi secara tidak langsung menggunakan kata demokrasi tetapi ia menggunakan nilai demokrasi yang dijelaskan pada Demokrasi Pancasila itu sendiri.

Datum 7:

Seluruh rakyat Indonesia yang saya cintai, Bapak-Ibu yang hadir di GBK. Saya dan Profesor Kiai Haji Ma'ruf Amin telah sepakat mewakafkan diri kamiberduauntukkesejahteraanhidup rakyat Indonesia. Kita memastikan lima tahun ke depan negara kita akan lebih kuat ekonominya. Untuk petani, untuk para nelayan, untuk para guru, buruh, untuk para dokter, untuk para PNS, TNI, Polri, seniman, pekerja kreatif, pengusaha kecil menengah, besar, baik anak muda ibu-ibu, bapakbapak. kita harus pastikan hidup ini lebih baik dari hari ini. Kami bertekad tidak akan ada lagi rakyat yang tertinggal di bawah garis kemskinan. Semuanya kita harus maju. Setuju?

Dalam datum ini, dalam wacana ini, Presiden Jokowi mulai meyakinkan orang Indonesia dengan mengatakan bahwa ia dan rekannya akan melakukan segalanya untuk orang Indonesia di sisi kesetaraan di mana semua orang memiliki hak yang sama untuk mendapatkan kesejahteraan mereka. Itu bisa berarti bahwa Presiden Jokowi menerapkan satu pilar Demokrasi Pancasila yang disebut kedaulatan rakyat. Data-data ini mewakili nilai demokrasi meskipun makna leksikal dalam kalimat tersebut tampaknya tidak mewakili demokrasi atau dalam hal ini dalam arti konotatif. Cara konotatif di sini berarti bahwa Presiden Jokowi secara tidak langsung menggunakan kata demokrasi tetapi ia menggunakan nilai demokrasi yang dijelaskan pada Demokrasi Pancasila itu sendiri.

Datum 8:

Terakhir, Bapak-Ibu dan saudara sekalian, bangsa Indonesia, rakyat Indonesia hari Rabu 17 April 2019 ini akan memberikan suara yang 
menentukan arah ke depan bangsa ini. Arah ke depan negara kita Indonesia, lima tahun ke depan. Oleh sebab itu pilihlah pemimpin yang tahu dan peduli dan tahu kebutuhan rakyat. Pilihlah pemimpin yang datang dari rakyat dan untuk rakyat. Pilihlah pemimpin yang selalu menempatkan kepentingan rakyat sebagai kepentingan nomor 1.

Dalam paragraf ini, Presiden Jokowi mencoba membujuk orang Indonesia untuk memilih kandidat yang akan memberikan segalanya untuk orang Indonesia. Ia menambahkan makna sistem demokrasi (pemerintahan rakyat, oleh rakyat, dan bagi rakyat) dalam pidatonya untuk meyakinkan rakyat Indonesia untuk memilihnya. Itu bisa berarti bahwa Presiden Jokowi menerapkan satu pilar Demokrasi Pancasila yang disebut kedaulatan rakyat. Data-data ini mewakili demokrasi meskipun makna leksikal dalam kalimat tersebut tampaknya tidak mewakili demokrasi atau dalam hal ini konotatif. Cara konotatif di sini berarti bahwa Presiden Jokowi secara tidak langsung menggunakan kata demokrasi tetapi ia menggunakan nilai demokrasi yang dijelaskan pada Demokrasi Pancasila itu sendiri.

\section{b. Analisis Wacana Kritis}

Setelah menemukan dan menganalisa representasi demokrasi dari segi makna leksikal, penulis kemudian menggunakan menganalisis suatu wacana yang terdapat pada teks pidato Presiden Jokowi. Dalam hal ini terdapat 2 bagian yakni analisis berdasarkan faktor internal dan faktor eksternal. Berdasarkan faktor internal, jelas bahwa teks pidato itu untuk mempromosikan ide Presiden Jokowi ketika dia menjadi kandidat presiden. Pidato tersebut adalah alat pendukung bagi Presiden Jokowi untuk meyakinkan orang Indonesia untuk memilihnya lagi sebagai presiden Indonesia berikutnya. Opini tersebut bisa dilihat dari cara Presiden Jokowi menyampaikan pidatonya. Dalam menyampaikan pidatonya, Presiden Jokowi sering menyebut kata yang ditujukan kepada masyarakat Indonesia. Secara kesimpulan, hal tersebut adalah bukti bahwa pidato-pidatonya membujuk orang Indonesia untuk memilih Jokowi.

Sedangkan berdasarkan faktor eksternal, berdasarkan temuan pada makna leksikal, ditemukan bahwa Presiden Jokowi menggambarkan Demokrasi Pancasila dalam beberapa hal yakni melalui makna denotasi dan makna konotasi. Dalam beberapa kasus, Presiden Jokowi langsung menggunakan kata demokrasi tanpa menjelaskan artinya. Namun, dalam kasus lain, alih-alih menggunakan kata demokrasi secara langsung, Presiden Jokowi sering menjelaskan nilai demokrasi terutama Demokrasi Pancasila. Selain itu, ada beberapa topik yang mewakili demokrasi seperti tentang ekonomi, kesehatan, pendidikan.

Sebagai bukti kampanye Presiden Jokowi yang berbicara tentang kesehatan dan pendidikan, BPS (2019) merangkumnya sebagai Indeks Pembangunan Manusia(IPM). Data dari BPS (2019) menyatakan bahwa selama 2014-2018 hanya ada peningkatan 2,49\% IPM. Dapat diartikan bahwa Presiden Jokowi harus berbuat lebih banyak ketika menjadi Presiden Indonesia untuk periode 2019-2024.

Sebagai bukti kampanye Presiden Jokowi yang berbicara tentang ekonomi dan penegakan hukum, ada beberapa fakta tentangnya. Yang pertama adalah data dari BPS (2019) menyatakan bahwa tingkat inflasi yang rendah sebesar 3\% di Indonesia membuat daya beli masyarakat tetap terjaga dan terus tumbuh. Meskipun, berdasarkan data dari katadata.com (2019), ada beberapa poin yang meleset dari target nasional selama kepemimpinan Presiden Jokowi seperti pertumbuhan ekonomi dan penegakan hukum. Target pertumbuhan ekonomi nasional adalah 7\% sementara dalam realisasinya bahkan tidak mencapai $6 \%$ dari pertumbuhan ekonomi.

\subsection{Pembahasan}

Berdasarkan temuan sebelumnya, demokrasi diwakili dalam banyak cara. Itu bukan hanya tentang pemilihan umum tetapi juga tentang ekonomi, hukum, pendidikan, dan kesehatan. Kata demokrasi diwakili dalam denotasi dan konotasi. Untuk makna denotasi, itu tentang pemilihan umum dan 
hukum. Sedangkan untuk makna konotasi, itu tentang ekonomi, hukum, pendidikan, dan kesehatan. Namun, karena pidato adalah tentang kampanye Presiden Jokowi, kata demokrasi yang diwakili dalam pidato adalah tentang cara bagaimana Presiden Jokowi membujuk orang Indonesia untuk memilihnya sebagai presiden berikutnya.

Representasi dapat dilihat dari makna leksikal yang digunakan dalam teks. Dalam dimensi teks, arti kata demokrasi yang digunakan dalam Presiden Jokowi sebagian besar mirip dengan pernyataan Abraham Lincoln yaitu pemerintah dari rakyat, oleh rakyat, dan untuk rakyat. Selain itu, istilah demokrasi dalam pidato itu sendiri juga diwakili Demokrasi Pancasila seperti yang dinyatakan oleh Asshiddiqie (2011). Ini berarti bahwa Jokowi menggunakan makna leksikal demokrasi yang memiliki makna leksikal itu sendiri.

Lebih jauh, kata demokrasi sebagian besar disampaikan dengan cara konotatif (3 konotatif, 5 denotatif). Secara konotatif, ini disampaikan berdasarkan tindakan yang telah dilakukan Presiden Jokowi selama masa pemerintahannya (2014-2019). Dia sering menyebut program yang dia lakukan adalah untuk orang Indonesia.

Dari penjelasan diatas, dapat diartikan bahwa Presiden Jokowi berusaha mengingatkan orang Indonesia bahwa dia telah melakukan banyak hal untuk masyarakat Indonesia. Ini mungkin cara yang baik dalam meyakinkan orang Indonesia untuk memilihnya. Namun, dia hanya mengatakan sedikit tentang program yang akan dia lakukan apabila dia adalah presiden terpilih berikutnya. Penting untuk memberikan pandangan masyarakat Indonesia tentang masa depan dalam lima tahun ke depan karena masa depan lebih penting daripada masa lalu.

Selain itu, bahasa yang digunakan dalam pidato adalah bahasa sehari-hari, bahasa sederhana, bahasa yang lebih mudah dipahami oleh orang Indonesia (kebanyakan dalam bahasa semiformal). Cara Presiden Jokowi menggunakan cara semiformal dalam pidato itu sejalan dengan penelitian sebelumnya yang dilakukan oleh Agustina (2017) dan dalam penelitiannya, dia juga melakukan penelitian tentang pidato Presiden Jokowi, terutama dalam pidato sambutan selama 2015-2016. Berdasarkan temuannya, dia juga menemukan bahwa Presiden Jokowi menggunakan cara semiformal dalam pidatonya. Presiden Jokowi menggunakan cara semiformal dalam beberapa kesempatan karena dia ingin berinteraksi dengan audiensi. Bahkan ketika kesempatan itu dalam situasi formal, Presiden Jokowi masih berusaha menyampaikan pidato dengan cara semiformal. Ini sejalan dengan penelitian saat ini di mana Presiden Jokowi sering mencoba menggunakan cara semiformal dalam situasi apa pun. Namun, penelitian saat ini berfokus pada representasi demokrasi dalam pidato kampanye Presiden Jokowi.

Pada penelitian lainnya, yakni penelitian tentang analisis pidato juga telah dilakukan oleh Mohammadi \& Javadi (2017). Dia melakukan penelitian tentang bahasa yang digunakan dalam kampanye pidato pemilihan presiden Amerika Serikat yang disampaikan oleh Donald Trump. Dia menganalisis pidato Donald Trump berdasarkan kata-kata dan kalimat. Selain itu, dalam penelitiannya, ia juga menemukan bahwa Donald Trump kebanyakan menggunakan bahasa sederhana, bahasa sehari-hari dalam menyampaikan pidatonya. Bahasa yang sederhana dapat membantu Trump untuk meminimalkan jarak antara dirinya dan audiens. Hal ini juga sejalan dengan penelitian saat ini di mana Presiden Jokowi sering mencoba menggunakan cara semiformal dan bahasa sehari-hari dalam situasi apa pun. Sementara Donald Trump juga menggunakan bahasa sehari-hari dalam menyampaikan pidatonya. Namun, penelitian saat ini berfokus pada representasi demokrasi dalam kampanye pidato Presiden Jokowi. Ini tentang bagaimana Presiden Jokowi mewakili demokrasi ketika dia menyampaikan pidato.

\section{KESIMPULAN}

Penelitian ini menunjukkan bahwa Presiden Jokowi menggambarkan demokrasi dalam dua tahap seperti denotasi (5 data) dan 
konotasi (3 data) dalam kampanye pidatonya. Selain itu, berdasarkan data, ada beberapa variasi topik yang mewakili demokrasi seperti tentang ekonomi, kesehatan, pendidikan, dan keamanan nasional. Data-data tersebut disampaikan secara denotatif dan konotatif.
Untuk makna denotasi, data yang ditemukan yakni topik tentang pemilihan umum dan hukum. Sedangkan untuk makna konotasi, data yang ditemukan yakni tentang ekonomi, pendidikan, dan kesehatan.

\section{DAFTAR RUJUKAN}

Agustina, L. (2017). Pemikiran Presiden Joko Widodo dalam Pidato Sambutan (Thought The Presiden Joko Widodo in A Greeting Speech). IAIN Antasari. South Kalimantan

Asshiddiqie, J. (2011). Hukum Tata Negara \& Pilar-Pilar Demokrasi. Jakarta: Sinar Grafika

Basrowi, \& Suwandi. (2008). Memahami Penelitian Kualitatif. Jakarta: Rineka Cipta.

BPS.go.id. (2019). Badan Pusat Statistik Indonesia. Diakses pada 10 November 2019 dari laman https://www.bps. go.id

CNN News.com. (2018). Manuver Jokowi Respons Isu PKI, Utang Negara, dan Bubar 2030. Diakses pada 24 Februari 2019 from https://www.cnnindonesia.com/nasional/20180408151236-32-289240/manuverjokowi-respons-isu-pki-utang-negara-dan-bubar-2030

Djajasudarma, F. (1999). Semantik 2: pemahaman ilmu makna. Bandung: Rafika aditama.

Fairclough, N. (1995). Critical Discourse Analysis. Boston: Addison Wesley.

Keraf, G. (2010). Diksi dan Gaya Bahasa. Jakarta: Gramedia

Mohammadi, M., \& Javadi, J. (2017). A Critical Discourse Analysis of Donald Trump"s Language Usein US Presidential Campaign, 2016. International Journal of Applied Linguistics \& English Literature, 6 (5): $1-10$.

Mukoyimah. (2018). Analisis Retorika Dalam Pidato Soekarno Perspektif Dakwah. [Tesis]. Semarang: Universitas Islam Walisongo.

Saharuna, H. (2016). Analisis Bahasa Kekuasaan Dalam Berita Politik Di Harian Fajar Makassar. [Online]. Diakses dari: $h t t p s: / / w w w . g o o g l e . c o m / u r l ? s a=t \& r c t=j \& q=\& e s r c=s \&$ source=web\&cd $=8 \&$ cad $=$ rja\&uact $=8 \&$ ved $=2$ ahUKEwj 1 mo3uw9XmAhXTT30KHRCoAlcQFjAHegQICRAC\&url=http\%3A\%2F\%2Fepri nts.unm.ac.id\%2F2645\%2F1\%2FARTIKEL\%2520HAMDANI.docx\&usg=AOvVaw0Fm12Xi7NLRbSP 11Lk4Fgu.

Soyomukti, N. (2013). Komunikasi Politik. Malang: Intrans Publishing Wisma Kalimetro.

Suwandi, S. (2008). Semantik Pengantar Kajian Makna. Yogyakarta: Media Perkasa.

Walija. (1996). Bahasa Indonesia dalam Perbincangan. Jakarta: IKIP Muhammadiyah Jakarta Press.

Wijana, I. D. P., \& Rohmadi, M. (2009). Analisis Wacana Pragmatik: Kajian Teori dan Analisis. Surakarta: Yuma Pustaka. 